ARTICLE

Received 10 May 2016 | Accepted 23 Jun 2016 | Published 2 Aug 2016

DOl: $10.1057 /$ palcomms.2016.51

\title{
Bad faith in All's Well That Ends Well
}

\author{
Andrew Hadfield ${ }^{1}$
}

\begin{abstract}
All's Well That Ends Well is a complicated and disturbing play that has a comic ending, but which seems anything but a comedy with a forced marriage based on bed-trickery between the reluctant Bertram and the feisty and witty Helena. Unsurprisingly, audiences have tended to side with Helena and the play has been classified as a "problem comedy" ever since William Lawrence identified this particular group of Shakespeare plays nearly a century ago. I want to argue in this essay that the play might better be classified as an "equivocation" play alongside Macbeth, Othello, and Troilus and Cressida and that the anxieties about fidelity, honesty and truthfulness in marriage need to be read in terms of the fear of religious tolerance/intolerance which dominated religious politics in the early years of James's reign before the passing of the Oath of Allegiance (1606). The play is notable for its interest in chop logic, which the clown in particular displays throughout the play, a counterpoint to the arguments of Bertram and Helena who want very different things, but who are bound together as future husband and wife. Although the language of treason and treachery is used throughout, the play is less interested in answering the question of how far one can trust a stranger within than the issue of how far one can accommodate the needs of others. This article is published as part of a collection to commemorate the 400th anniversary of William Shakespeare's death.
\end{abstract}

\footnotetext{
${ }^{1}$ School of English, University of Sussex, Brighton, UK Correspondence: (e-mail: A.Hadfield@sussex.ac.uk)
} 
H ow should we classify Shakespeare's plays? Generic approaches are, of course, sensible and valuable. But do they hide things that we might otherwise see? If we read plays across genres but in terms of dates might we learn more about the concerns of particular authors who were thinking about certain issues that they explored in a variety of literary styles and modes? In this essay, I want to analyse a work that divides critics in order to make the case that if we read the play in terms of other plays a pattern will emerge enabling us to see it as a drama structured around the particular anxieties oaths and promises precipitated by the religious conflicts of the early years of James' reign.

All's Well That Ends Well is, arguably, the most troubling of Shakespeare's comedies. Its comic nature has long perplexed critics because the cunning use of a bed trick-substituting one woman for another unbeknown to the man in question-serves to unite one willing partner, Helena, with an unwilling one, Bertram. Helena is granted her heart's desire by the King of France when she cures his fistula, unfortunately selecting as her prize a reluctant husband who, unlike most audiences, is immune to her charms. Trying to make sense of the play Nuttall registers its contradictory pulls: "All's Well That Ends Well is a strange mixture of cynicism and idealism” (Nuttall, 2007: 249). Traister also feels obliged to read the play as a hybrid, a quasifeminist fable, because it is "peculiar among Shakespeare's comedies, the only one in which a woman selects an unwilling marriage partner", but one that ends compromising its heroine because she threatens to transgress boundaries: "Within the play, the problem of Helen is solved, however uneasily, by containing her within the folkloric plot as the clever wench who has won her husband" (Traister, 2003: 333, 345). For Kastan, the "epigrammatic title of Shakespeare's play may virtually serve as a definition of comedy", and the drama, in exploring the "limitations of formal control" eventually "makes us recognize the inadequacy of a conception either of comedy or of ethical behaviour that focuses exclusively on ends" (Kastan, 1985: 579, $580,585)$.

My anxiety about such readings is not that they are mistaken: all three readings are full of insights about the complicated nature of the play-and, as a reading of the play in terms of its form, it is hard to imagine that Kastan's succinct analysis of the comic nature of All's Well can be bettered. Rather, it is that they read the play in terms of the familiar category of the "problem comedy", alongside Troilus and Cressida, and Measure for Measure. The notion of the "problem comedy" was invented by F. S. Boas in 1896, when he sought to compare a particular phase of Shakespeare's writing to the exciting and troubling work of Ibsen and Shaw, who were eager to use comedy to explore vital social and political themes, in particular, women's status and rights (Smith, 2008: 25). Influential books by W. W. Lawrence, Shakespeare's Problem Comedies (1931), and E. M. W. Tillyard, Shakespeare's Problem Plays (1951), cemented the genre in the critical imagination (Schanzer, 1963: 12-13). When so many of Tillyard's judgements are attacked or ridiculed, it might seem odd that this one has escaped through the net.

The problem with the notion of "problem comedies" is whether it describes something real, a tangible, definite stage in Shakespeare's writing career, as well as a particular approach to genre. If other factors are considered we may have to think about reading the play in a different way. There has been a vigorous recent discussion of the dating and authorship of All's Well, with Laurie Maguire and Emma Smith arguing that the play was coauthored with Thomas Middleton and that it should be re-dated to 1606-1607 (Maguire and Smith, 2012: 13-15). Their claims have not met with universal acceptance but it is fair to state that, while some critics are sceptical of the case for Middleton's authorship, a critical consensus is emerging that the play is probably later than was once thought, and is assumed by many now to have been written nearer to 1607 than 1603 (Skinner, 2014: 315-317). There are serious precedents for the later date. In his edition of the play, published in 1912, John Livingston Lowes argued on metrical grounds that All's Well belonged with the romances and in 1980 Barron Brainerd's statistical analysis of lexical variants designed to determine a chronology of Shakespeare's plays made a strong case that the date of the play should be changed to 1607 , a conclusion he highlighted in his study, expressing surprise that conventional dating was so inaccurate in this particular case (Shakespeare, 1912: introduction, vii-x; Brainerd, 1980: 229). If Smith and Maguire are right, then All's Well needs to be read alongside a cluster of tragedies: King Lear, Macbeth, Antony and Cleopatra, Coriolanus, and Timon of Athens. It would then become the one obvious comedy among a host of much darker plays which, for some commentators, were written as a result of depression (Beale, 2014). Perhaps such company makes the reshuffling of dates seem less plausible; perhaps, it explains why it is such a problematic comedy. However, my point is that even if All's Well is left with its original date of $1604-1605$, these plays should probably be discussed together as works that are related to anxieties about religious toleration. Many, in particular, King Lear, Macbeth, and Coriolanus, are directly concerned with issues of fidelity and treason, and whether policies designed to force subjects with conflicting, equivocal and ambiguous loyalties to pledge their allegiance to the state may end up doing more harm than good. If the date of All's Well has to be revised to $1605-1607$, then, I would argue, this cluster is best read as Gunpowder Plot plays, nervous dramas that are directly concerned with the complex problem of the enemy within (Dutton, 2008).

The crown's response to the Gunpowder Plot was to impose the Oath of Allegiance as a means of ensuring loyalty. The Oath gave subjects a stark choice. The loyal subject had to acknowledge James as the "lawful and rightful King of this realm" and publicly declare that the Pope had no power to depose the king or to "discharge any of his Subjects of their allegiance and obedience to his Majesty", a confrontational formula (Ryan, 1942: 162). The most significant sections of the oath required individuals to denounce the claims of the Papacy without reservation:

And I do believe and in conscience am resolved, that neither the Pope nor any person whatsoever, hath power to absolve me of this oath, or any part thereof, which I acknowledge by good and full authority to be lawfully ministered unto me, and do renounce all pardons and dispensations to the contrary: And all these things I do plainly and sincerely acknowledge and swear, according to these express words by me spoken, and according to the plain and common sense and understanding of the same words, without any Equivocation, or mental evasion, or secret reservation whatsoever: And I do make this recognition and acknowledgement heartily, willingly, and truly, upon the true faith of a Christian: So help me God. ${ }^{1}$

Britons now had to swear that they had not equivocated, stated one thing When taking the Oath while really meaning something else, the act removing the possibility of ambiguity and deception. The Oath was disseminated widely in various proclamations as various anti-recusancy laws were passed in order to force the hand of subjects wavering in their loyalty (Larkin and Hughes, 1973: 84, 96, 111, 118). James, whose reign was eagerly anticipated by many Catholics hoping for a more ecumenical regime that did not persecute other confessional allegiances, were dismayed (Nicholls, 1991: Pt. 2). Many had to pay exorbitant fines which helped fund James's generosity towards his favourites, and the Oath was widely viewed as a cynical way of supporting 
James's style of rule (La Rocca, 1978). They were now divided even more than before, as Questier has argued, the Oath claiming to be moderate in only demanding temporal obedience while ensuring that a Protestant public sphere would emerge. In effect it turned "a denial of the deposing power into what could plausibly be regarded as a rejection of the papal primacy", and was, therefore, "the ideological equivalent of the oath of supremacy" (Quester, 1997: 320-321). According to Patterson, one of "James's conspicuous achievements was to bring English Protestants together in a common front which, for the moment at least, obscured the theological and ecclesiological differences among them" (Patterson, 1997: 122).

The Oath made formal what had been policy for many years, since the Jesuit mission of the late 1570s in the wake of the Papal Bull declaring Elizabeth to be an illegitimate ruler who should be deposed by proper Catholic servants of the Pope (Alford, 2012; Lake, 2016). It did not so much mark a departure in English/British politics, but, as Questier's comment indicates, a repetition of an earlier pressure point, the imposition of the Oath of Supremacy after Henry VIII's Reformation (Hadfield, forthcoming: Pt. 1). This continuity is noted by Guy in whose judgement "Elizabeth's last decade may be interpreted as the first of the early Stuarts" (Guy, 1994: 149). James's accession had initially seemed like the dawn of a new tolerance for Catholics after the harsh years of the second half of Elizabeth's reign, especially after the end of the Anglo-Spanish wars which were concluded by the signing of the Treaty of London (1604). Even though the response to the plot was not the wholesale repression of Catholics that many anticipated, the Oath signalled that conformity would be imposed with a vigour that would match that of the previous regime (Nicholls, 1991: Pt. 1). Catholics were regarded as potential traitors who would lie their way out of trouble unless they were rigorously policed and controlled.

If All's Well is informed by contemporary religious issues then we do not have to assume that it has to be dated after the Gunpowder Plot, even if internal evidence seems to point towards a later date, as I shall argue in this essay. ${ }^{2}$ A clue to the central concerns of the play is provided in the chop logic of the clown, servant to the Countess, Bertram's mother, in the first scene in which he appears. The clown explores the significance of the words of the marriage ceremony in The Book of Common Prayer, which claim that husband and wife cannot be separated, their union "signifying the mistical union that is betwixt Christ and his Churche", concluding with the exhortation, "Those whome God hath joined together, let no man put asunder" (Cummings ed., 2011: 157, 159). The clown provides the obviously fallacious argument:

He that ears my land spares my team, and gives me leave to in the crop; if I be his cuckold, he's my drudge. He that comforts my wife is the cherisher of my flesh and blood; he that cherishes my flesh and blood loves my flesh and blood; he that loves my flesh and blood is my friend; ergo, he that kisses my wife is my friend. If men could be contented to be what they are, there were no fear in marriage; for young Charbon the Puritan and old Poysam the Papist, howsome'er their hearts are sever'd in religion, their heads are both one; they may jowl horns together, like any deer I' th'herd. (Shakespeare, 1959: $1.3 .42-54)^{3}$

The first part of the speech, quibbling on ploughing as a sexual pun as well as a process that yields produce, argues that an adulterer helps and loves the cuckold because they both love the same woman and are therefore all part of the same flesh and blood which forms the mystical union in the marriage ceremony outline in The Book of Common Prayer. The speech makes a perverse case for unity, arguing that the universal appetite for adultery is what binds people together. In fact, this illicit desire connects both young and old, Catholic and Puritan. The choice of these particular religious identities is surely not coincidental. The formal significance of the sentence would seem to be that everyone commits adultery, but it can be read another way. Perhaps it is the papists and the puritans who desire to undermine marriage, making life more difficult for everyone else. And it surely cannot be irrelevant that Elizabeth described herself as married to the realm she governed, and James represented England as a body of which he was the head, making them one flesh (James I and VI et al., 1994: 144; Elizabeth, 2000: 59). In contrast the papists and puritans are like rutting deer, fighting to ravish the land regardless of the cost. They might imagine that they love the object of their adultery, and have the best interests of a settled union in mind, but reality would suggest that they are really adulterers undermining holy matrimony.

The plot of All's Well is centered on oaths, public promises that have to be made in order for a marriage to be solemnized (Kerrigan, 2016: 327-335). Marriage practices in early modern England were a mixture of the informal and the strongly binding, with apparent promises made between couples often leading to confusion as to whether an agreement to marry had actually taken place, and the forceful power of an oath binding a couple together forever in the eyes of God and the community in which they lived (Cressy, 1997: 336-349). When projected marriages went wrong, either through a promise being misunderstood, or one of the parties deciding not to go ahead with the ceremony, the result was invariably disastrous for at least one of the couple, especially the woman (Hubbard, 2012: Chapter 2). The confusion surrounding marriage agreements in the play clearly reflects a perceived social problem as All's Well demonstrates how tough and heartbreaking life can be when the course of true love does not run especially smoothly. But it is also an ideal vehicle for commenting on the nature of oaths as binding promises in the years surrounding the Gunpowder Plot, with the clown's speech early in the play making little effort to disguise the relationship between the public and the private in a wider sense than that of the public vow of a couple to regulate and order their private lives. Shakespeare is able to comment on the problematic marriage between the monarch and the realm, and, far more significantly, the uncomfortable situation of individuals in Jacobean England who were forced to negotiate swearing oaths to incompatible authorities who did not necessarily have their best interests at heart: the church and the state. The result was a concentration on ways of making promises that did not commit an individual absolutely, and which did not actually break oaths and become lies. Equivocation and cunning verbal strategies were, accordingly, widespread, and not restricted to besieged Catholics (Hadfield, forthcoming: Chapter 3).

Soon after the Countess's encounter with the clown, she meets Helena and manages to secure an admission that the young woman loves her son and so they might well have a future relationship as mother and daughter-in-law:

Count. You love my son. Invention is asham'd Against the proclamation of thy passion To say thou dost not. Therefore tell me true; But tell me then, 'tis so; for, look thy cheeks Confess it, $t$ ' one to th' other, and thine eyes See it so grossly shown in thy behaviors That in their kind they speak it: only sin And hellish obstinacy tie thy tongue,

That truth should be suspected. Speak, is't so? If it be so, you have wound a goodly clew; If it be not, forswear't: howe'er, I charge thee, As heaven shall work in me for thine avail, 
To tell me truly.

Hel. Good madam, pardon me.

Count. Do you love my son?

Hel. Your pardon, noble mistress.

Count. Love you my son?

Hel. Do not you love him, madam?

Count. Go not about; my love hath in't a bond

Whereof the world takes note. Come, come, disclose

The state of your affection, for your passions

Have to the full appeach'd.

Hel. Then, I confess,

Here on my knee, before high heaven and you,

That before you, and next unto high heaven,

I love your son.

My friends were poor, but honest; so's my love.

Be not offended, for it hurts not him

That he is lov'd of me: I follow him not

By any token of presumptuous suit[.] (1.3.168-193)

This is a complex and dense passage that reflects on more than simply a problematic marriage suit. The passage seems benign enough, but what takes place is that the Countess uses her verbal skills, social convention and relationship to Helena, to extract a confession: put another way, she acts as both good and bad cop in an interrogation. Helena resists, trying to deflect her questions by responding with some of her own, a tactic also employed by Iago in Othello in order to inflame the jealousy of the Moorish general (Hadfield, 2016: 62-64). When Helena speaks of a mother's love the Countess refuses any comparison to youthful passion because her love is sanctified by a bond, whereas Helena's is not. Cornered and with no room left for manouver, Helena confesses, but works hard to minimize the damage that her passion will cause, claiming it will have no impact on anyone other than herself because she wants to keep it hidden.

Here we witness varieties of love and forms of promise in conflict. The Countess can assume superiority by virtue of her age, social position and legitimacy; Helena holds no cards and her bodily passion betrays her, placing her in the Countess's power. Helena's love may be powerful and all-consuming but, having no legitimacy, it makes her weak and vulnerable, exactly like the puritans and papists in the clown's speech. She claims that her love has no effect on anybody and is impotent, which is ironic when read in the light of future events, specifically her bargain with the king to obtain Bertram's hand, but it is in line with the claims of Jesuits such as Edmund Campion that their mission was spiritual not political and would not precipitate rebellion against the crown (Kilroy, 2015: 392). Their love and duty were directed at saving peoples' souls, not initiating regime change. In this exchange Helena tries as hard as she can under interrogation from the Countess to minimize the influence of her passion on the world, just as Catholic missionaries in England argued that their aim was to save souls and not to interfere in politics. The Gunpowder Plot, like Helena's later actions in securing her marriage to Bertram, vitiated both cases, sincere as they undoubtedly were when the promise was made. Oaths were meant to be binding long after they were uttered, performative speech acts that circumscribed the behavior of the swearer who had made a promise about future behavior (Kerrigan, 2016: 9). But it was hard to keep oaths in times of bewildering religious change and what might seem like a reasonable promise at one point could be classified as treason soon afterwards. The Countess demands that Helena tell the truth about her love for her son and Helena does all she can to avoid making a promise to tell the truth and so swearing an oath. An audience's sympathies are undoubtedly with Helena here, as the Countess tries to force the younger woman into a binding promise, using the language of sacred oaths and assuming an authority through the verb "charge" which can demand the truth and make the speaker swear or forswear. Parents had rights, of course, but surely the Countess is overstepping the mark in arguing that her love has the binding force of law whereas Helena's has no reality or status.

The Countess may have a technical point, and it is well-attested by historians that most marriages in this period had at least some element of familial agreement. However, as Houlbrooke has pointed out, while post-Reformation writers on marriage "insisted upon the due obedience of children, they also urged proper consideration upon parents" (Houlbrooke, 1984: 69). The Countess is overstepping the mark in insisting that Helena declare the truth about her feelings for her son, which could be considered an abuse of authority. Her demands might be regarded as illegitimate, which is exactly how Catholic writers saw Protestant attempts to impose oaths of obedience on those who owed true allegiance to the Papacy. Protestant writers made the opposite case: it was the Papacy that was abusing its authority in demanding the obedience of members of the church over those of secular rulers and their laws (Zagorin, 1990: 1-14). The exchange would certainly have made many in the audience uncomfortable in posing questions of loyalty and in what circumstances a subject could refuse to swear an oath, among the most significant political issues in late Elizabethan and early Jacobean Britain. As many authorities on oaths argued, swearing an oath one could not keep was worse than refusing to swear it, however, one achieved that goal. Equivocating, or practicing "mental reservation" (completing a sentence silently so that only God would hear, as in, "I am not a priest" (silent) "of Zeus") was preferable to lying before God or making a promise that violated one's conscience and which one could not keep (Gray, 2013). We witness the Countess exceed her authority and force Helena to swear an oath she cannot promise to keep: she cannot know that she will always love her son, nor that she will never act upon her feelings, especially, as the Countess points out, there is no contract between them, but, of course, matters may change.

Fortunately, this is a comedy and the Countess actually has Helena's best interests at heart. It transpires that what Helena imagines, the oath she thinks she is being called to swear, is at odds with the Countess's plans, as Bertram's mother is eager to encourage her suit rather than seeking to prevent it. Even so, this is an especially uncomfortable scene in a challenging play. The clown's earlier comments about marriage to the Countess, which she dismisses, calling him "a foul-mouth'd and calumnious knave" (1.3.54-55) immediately after his speech, overshadow the exchange between the Countess and Helena, and make an explicit link between the personal and the political. The Countess uses slegal language with her clown as well as with Helena, as the term "calumny" was used in defamation statutes to define slanderous language (Sokol and Sokol, 2000: 207). But the clown is only pointing out the logic of oaths of loyalty, which were like unhappy marriages. In then forcing the issue with Helena by making the young woman declare her hand, the Countess risks causing the sort of misery that the clown describes. If Helena wants to marry Bertram and Bertram does not want to marry Helena there are only two solutions, both of which will leave at least one, possibly both, unhappy: they either marry or they do not. The clown describes what looks like the opposing case when a marriage partner loves someone else and all parties simply have to make the best of an unhappy situation. Perhaps the real moral of this scene, one that overshadows the action of the play, is that there is no right solution when parties who have to be together cannot agree what to do and want opposing things. Not everyone can have what they want and the best solution is probably to compromise-but at what cost? The Countess's decision to act decisively leads to qualified success in All's Well, but it is not clear 
how Bertram will behave after the marriage at the end of the play and the clown's description of an adulterous marriage may well describe what the future has in store for the couple. And, of course, swearing oaths to one person while one's heart was elsewhere-Helena has to swear to abandon her suit, Bertram has to agree to a union he does not want-must have seemed like an uncomfortable reality for those forced to swear allegiance to powers they did not want to serve.

When Bertram is forcibly betrothed to Helena by the king, grateful that Helena has cured him of his painful disease, he (Bertram) is told that his equivocal response does in fact constitute a binding promise. Objecting to her rank and his lack of affection for Helena, Bertram is at first clear about his feelings and intentions: "I cannot love her nor will strive to do't" (2.3.145). But when pressurized by the king, who, like Herod enraptured by Salome, has made a rash promise that he now has to keep, Bertram, as his loyal subject, has to submit to his monarch's demand. However, he uses words that, like Helena's before the Countess, are as evasive as they can realistically be:

Pardon, my gracious lord; for I submit My fancy to your eyes. When I consider What great creation and what dole of honour Flies where you bid it, I find that she, which late Was in my nobler thoughts most base, is now The praised of the king; who, so ennobled, Is as 'twere born so (2.3.167-173).

Bertram does not say that he loves Helena, that he is happy to marry her, or that he might come to love her given time and familiarity. Rather, like a reluctant oath-taker who has been coerced into agreeing to something he does not want to do, he submits while trying to leave himself as large a loophole as he can. He agrees to see the matter-and Helena-through the king's eyes, submitting to them, which makes it clear that he does not see her as the king sees her and that this is not a decision that he has reached based on his own volition. The sudden, apparent ennoblement of Helena surely satirizes James's notorious tendency for promoting useful commoners to the nobility, something Shakespeare satirizes in others plays written in this period (Hadfield, 2003). Bertram accepts her elevation but is clear that she is a lady "as "twere born so", which, of course, means that he does not really consider her one (just as many did not really think that those ennobled by James were proper aristocrats). ${ }^{4}$ The king has the power to do what he wants, and can make his unwilling subjects swear oaths and make promises they do not want to keep. Bertram does not pretend that he loves Helena, merely that he recognizes what the king can do. When he states, "I will take her hand" (2.3.176) the statement and the gesture it describes are equivocal. Is this "hand-fasting" ceremony, a promise to marry in the future as was common practice at the time, acknowledged by both parties? (Cressy, 1997: 268) And, even if it is, does it count as a promise if one party is going through the motions? What was a binding contract to one could be a trifle to the other, a promise that was not understood, an agreement that was not binding, or something that could always be cast aside if a better offer materialized. The king, like the Countess forcing the truth out of Helena, assumes that he has initiated a "contract" (178), but the final line of his speech before he leaves makes a comparison that undermines his assumptions: "As thou lov'st her/Thy love's to me religious; else, does err" (182-183). This is meant to bind the two parties but it can be inverted: because Bertram does not love Helena, as he has clearly stated, then surely his love to the monarch cannot be religious. The king imagines that this is an error, but, for Bertram it is the truth. Yet again, we witness a figure in authority overstepping the mark and assuming that he has the power to impose a binding oath when his demands actually make the opposite case more likely, exactly how many felt about being forced to swear oaths to an authority they could not fully obey.

Bertram is and is not married after the ceremony takes place, as he deliberately places himself in an anomalous position as he explains to Parolles:

Ber. Undone and forfeited to cares for ever!

Par. What's the matter, sweetheart?

Ber. Although before the solemn priest I have sworn,

I will not bed her.

Par. What, what, sweetheart?

Ber. O my Parolles, they have married me!

I'll to the Tuscan wars, and never bed her.

Par. France is a dog-hole, and it no more merits

The tread of a man's foot: to the wars! (2.3.263-71).

Bertram's response to being forced into a union he does not desire is to flee, to retreat into the male world of military endeavour in order to escape female company that has claims upon him. Parolles' calling Bertram "sweetheart" is ironic and mockingly places male friendship above the bonds of marriage: at one level the joke here works in suggesting that reluctant bridegrooms will seek solace in each other, perhaps indicating that when forced into the open groups will bind together more forcefully than before rather than conforming to the demands of a hostile authority. Moreover, this flirtation with same-sex desire only lasts so long: Parolles' description of France as a "dog-hole" is hardly subtle in its connotations: Bertram will find better holes to satisfy him in Italy. Together the two men can continue to sow their wild oats, as soldiers entertained presumably by camp followers. In rejecting regulated sexual relations with Helena-which will provide her with grounds for divorce as the only possible way to dissolve a marriage was on the grounds of a failure to produce childrenParolles makes clear that Bertram can seek solace elsewhere (Murray, 1990; Kane, 2008). Bertram, back in Paroles' company, adopts the cynical tone of his male companion: "Wars is no strife/ To the dark house and the detested wife" (2.3.287-288). The forced marriage, perhaps like a forced oath of loyalty, seems to create more problems than it solves, producing dangerous, dis-satisfied exiles who regard their country with contempt. Mariana, the friend of Diana who helps Helena entrap Bertram, and who has already witnessed the behavior of Parolles, provides the necessary judgement on their motives and behavior in language that describes uncontrolled desire, and which clearly refers more generally to unregulated behavior indifferent to binding promises: "their promises, enticements, oaths, tokens, and all these engines of lust, are not the things they go under" (3.5.18-20).

Bertram may be a decent enough young man, but the coercive behavior of the authorities has led him into bad company and distorted his moral compass. Everyone agrees that Parolles is a bad lot and that he is someone who sets no value on telling the truth, a habitual liar, his name implying that he produces endless words (paroles) that have no relation to any deeds that they may describe. A French lord warns Bertram that Parolles cannot be trusted: "in mine own direct knowledge, without any malice, but to speak of him as my kinsman, he's a most notable coward, an infinite and endless liar, an hourly promise-breaker, the owner of no one good quality worthy your lordship's entertainment" (3.6.8-12). The speech is, of course, funny, moving swiftly from the lord's selfprotecting opening and guarantee that he speaks the truth because he bears no malice in speaking ill of his kinsman, through four clauses which dismiss Parolles' virtues as non-existent. But these words have a serious purpose in supporting Mariana's judgement in the previous scene, ensuring that her words cannot be dismissed as female gossip, as well as reminding the audience yet again that 
breaking promises and lying is a legal issue, through the use of the word "malice". The gentleman takes care to distance himself from any accusation that he is acting in bad faith, uttering his words with "malice", a legal term in the early modern period, which defined the hostile intention behind words that could then be classified as criminal, in particular, treason (Bellamy, 1979: 21-22). A picture of Parolles is being carefully drawn for the audience, which culminates in the sting that exposes him as a traitor prepared to sell secrets to the enemy to save himself-the fate of many on both sides of the confessional divide in early modern Europe. ${ }^{5}$ Bertram, a man who starts off being somewhat equivocal eventually keeps company with habitual liars.

The fates of Helena, Bertram and Parolles are carefully linked in the play. Helena confesses the truth when there is no way out; Bertram flees to the wars when he is forced to equivocate over a binding oath; and Parolles promises to tell his captors whatever they want to know, all understandable responses to situations in which oaths are stretched to and beyond breaking point. But, even at this dangerous stage Parolles cannot resist leaving open the possibility of inventive lying: "I'll speak that/Which you will wonder at" (4.2.85-86). The quibble here centres on "wonder", as what Parolles wants the soldiers to believe is that they will be amazed at what he is able to reveal. The First Soldier tries to close the inherent ambiguity in the word when he responds, "But wilt thou faithfully?" (86), as he fears that Parolles will tell them another tall tale, which is what he does in the following scene when he is fooled into slandering Bertram. The play hints at a more general point, as well as a topical meaning. Catholic attacks on the spying network overseen by Sir Francis Walsingham argued that it was the government Which had induced its victims into false confessions, or, had simply made up the case against supposed Catholic traitors. And, if the play is to be dated as a post-Gunpowder Plot play, it is surely relevant that Catholic accusations circulated widely that the plot had been orchestrated and invented by Sir Robert Cecil (Lake, 2016: 7677, 82-83; Nicholls, 1991: 213-218). When the incensed Bertram demands that Parolles should be whipped and publicly humiliated, because he is a "Damnable both-sided rogue" (213), the Second Lord pointedly reminds Bertram that "This is your devoted friend, sir, the manifold linguist, and the armipotent soldier" (227-228). Bertram does not think of himself as a traitor, or as someone who encourages and tolerates treason, but that is where his actions have led him. Furthermore, an audience would have been well aware that the fate of a Parolles in early modern England beyond the fictions of the playhouse would have been far more severe and that Bertram himself would have been lucky to escape with only a shameful and painful beating.

The play ends on an equivocal note. In response to the king's question Diana describes Bertram's anomalous state after the bedtrick in words that can only be understood by those who been party to the deception and which will confuse those who do not yet know that the women were switched:

King Wherefore hast thou accus'd him all this while?

Dia. Because he's guilty and he is not guilty.

He knows I am no maid, and he'll swear to't;

I'll swear I am a maid, and he knows not.

Great king, I am no strumpet; by my life

I am either maid or else this old man's wife (5.3.283-287).

The riddle tells the truth only if we accept Diana's statement that Bertram "knows" that she is not a maid, which is what he thinks is the truth. Bertram is guilty if we think that his intentions matter, which, if we are following the legal logic of the play, they do. As Rebecca Lemon has pointed out, many people were executed for treason in England in the sixteenth and seventeenth centuries, but hardly anyone actually did anything (Lemon, 2006: 2, 5, 10). They uttered words that were thought to express malicious intentions: imagining (compassing) the death of the king played a major role in many treason trials (Bellamy, 1979: 9; Barrell, 2000). Bertram intends to have sex with Diana and imagines (compasses) that he has done so, but he has, in fact, slept with Helena, who now, finally becomes his wife in earnest, so he has committed no actual crime with his body, just with his mind. However, given the close relationship in the play between marriage vows and other forms of oath that signify political and religious loyalty, the audience is uncomfortably aware that the one can easily stand for the other and that Bertram is, as Diana, states, a guilty man.

All's Well concludes happily, unlike a play it resembles in many ways, Othello. That play contains some nasty stabbings, but the murder which precipitates the tragedy is based on the central character believing something has taken place which has not, a deception which bears a close relationship to that practiced on Bertram, but which here, precipitates a comic ending. At times bad faith and words produce desirable results; at others, equally bad faith and words have disastrous effects. All's Well concludes with a situation as confusing and morally complex as it started. Bertram promises before the king to love Helena as she has produced his ring and is now pregnant with his child: "If she, my liege, can make me know this clearly/I'll love her dearly, ever, ever dearly" (5.3.309-310). But it is hard to understand what has really changed other than his mind (assuming he is telling the truth). The plot has revolved around oaths, equivocation, promises, broken promises, lies and all sorts of bad faith, but in the end all has ended well. The play does not answer the central moral issue it raises, whether it is better to make people tell the truth in public or whether things should be left to follow their own course. On the one hand we witness a complicated and possibly dangerous plot which highlights a range of hazards that confronted people in early modern Europe-treason, warfare, and social, political and religious divisions-and which only concludes when an individual makes what might seem like an arbitrary change. Furthermore, it might be argued, we have no idea whether this marriage will work. On the other, reading the play in a more optimistic manner, the plot proves worthwhile because the girl ends up with the boy, which is what should happen in a romantic comedy.

It is not surprising that All's Well has been read as a play with a "Catholic aesthetic" (Woods, 2013: 132). The play dramatizes the reality of life for many Catholics living in Jacobean England around the time of The Gunpowder Plot. ${ }^{6}$ But the truth is that more likely a work which acknowledged how hard it was to live as a public, political animal when an anxious government sought to create conformity through the imposition of oaths. Refusing or pretending to swear oaths was not only perilous for the individual concerned but could easily be seen as bad faith; authorities imposing oaths that people could not be expected to keep was, however, equally fraught with danger and, just as much a case of bad faith. In the comic world such problems could be sorted out but the somewhat bleaker message of All's Well is that the real world was not likely to be quite as friendly and forgiving, a case of the play indulging in a game of make-believe that the audience would have understood. Presumably some of the audience found the play light-hearted relief that provided a welcome distance from the anxieties of everyday life while others were reminded that there could be no escape from the consequences of having to make promises one might not be able to keep. 


\section{Notes}

1 The Statutes of the Realm 3 James 1, c. 4.

2 The argument that All's Well post-dated the plot was put forward by John Dover Wilson and Arthur Quiller-Couch in their edition of 1929, arguing that the bawdy description of "underminers and blowers-up" (1.1.118-119), referred to the plot, as do the words "the common course of all treasons": see Shakespeare, 1929: 122, 129-130. Modern editors are often sceptical: see Shakespeare, 1993: introduction, 24.

3 All subsequent references to this edition in parentheses in the text.

4 In "To Penshurst", Jonson includes a reference to "high-swol'n Medway", which is a sneering remark aimed at the king's favourite Robert Carr, who had just been made Viscount Rochester, the chief town on the River Medway: see "To Penshurst", line 31, (Jonson, 2012: 7, 212).

5 For one contemporary case, that of Copley, see Dimmock and Hadfield, 2014: 50-60; Copley, 2016.

6 Wilson points out a large number of Catholic references in the play: Wilson, 2005.

\section{References}

Alford S (2012) The Watchers: A secret history of the reign of Elizabeth I. Penguin: London.

Barrell J (2000) Imagining the King's Death: Figurative treason, fantasies of regicide, 1793-1796. Oxford University Press: Oxford.

Beale SR (2014) "Shakespeare could have been depressed when he wrote Timon of Athens, Simon Russell Beale says". The Daily Telegraph 25 August.

Bellamy J (1979) The Tudor Law of Treason: An introduction. Routledge: London.

Brainerd B (1980) The Chronology Of Shakespeare's Plays: A Statistical Analysis. Computers and the Humanities; 14 (4): 221-230.

Copley A (2016) A Fig For Fortune: A catholic response to the Faerie Queene. In: Monta SB (ed). Manchester University Press: Manchester, UK.

Cressy D (1997) Birth, Marriage and Death: Ritual, Religion, and the Life-Cycle in Tudor and Stuart England. Oxford University Press: Oxford.

Cummings B (ed) (2011) The Book of Common Prayer: The texts of 1549, 1559, and 1662. Oxford University Press: Oxford.

Dimmock M, Hadfield A (2014) Two sussex authors: Thomas Drant and Anthony Copley. In: Dimmock M, Hadfield A and Quinn P (eds). Art, Literature and Religion in Early Modern Sussex. Ashgate: Farnham, UK, pp 41-60.

Dutton R (2008) Ben Jonson, Volpone and the Gunpowder Plot. Cambridge University Press: Cambridge, UK.

Elizabeth I (2000) Collected Works. In: Marcus LS, Mueller J and Rose MB (eds). The University of Chicago Press: Chicago, IL.

Gray JM (2013) Oaths and the English Reformation. Cambridge University Press: Cambridge, UK.

Guy J (ed) (1994) The establishment and the ecclesiastical policy. In: The Reign of Elizabeth I: Court and culture in the last decade. Cambridge University Press: Cambridge, UK, pp 126-149.

Hadfield A (2003) Timon of Athens and Jacobean politics in Shakespeare Survey; 56, 215-226.

Hadfield A (2016) Jonson and Shakespeare in an Age of Lying. Ben Jonson Journal; 23 (1): 52-74.

Hadfield A (forthcoming) Lying In Early Modern English Culture From The Oath Of Succession To The Oath Of Allegiance. Oxford University Press: Oxford.

Houlbrooke R (1984) The English Family, 1450-1700. Longman: London.

Hubbard E (2012) City Women: Money, Sex, \& the Social Order in early Modern London. Oxford University Press: Oxford.

James I, James VI (1994) Political Writings. In: Sommerville JP (ed). Cambridge University Press: Cambridge, UK.

Jonson B (2012) Bevington D, Butler M and Donaldson I (ed) The Cambridge Edition of The Works of Ben Jonson; 7 Vols, Cambridge University Press: Cambridge.

Kane B (2008) Impotence and Virginity in the Late Medieval Ecclesiastical Court of York. University of York: York, Borthwick paper no. 114.

Kastan DS (1985) All's Well That Ends Well and the limits of comedy. ELH; 52 (3): 575-589.

Kerrigan J (2016) Shakespeare's Binding Language. Oxford University Press: Oxford.

Kilroy G (2015) Edmund Campion: A Scholarly Life. Ashgate: Farnham, UK

La Rocca JJ (1978) James I and his Catholic subjects, 1606-1612: Some financial implications. Recusant History; 18 (3): 251-262.
Lake PL (2016) Bad Queen Bess? Libels, Secret Histories, and the Politics of Publicity in the Reign of Queen Elizabeth I. Oxford University Press: Oxford.

Larkin JF and Hughes PL (eds) (1973) Stuart Royal Proclamations: Volume I: Royal proclamations of King James I, 1603-1625. Oxford University Press: Oxford.

Lemon R (2006) Treason By Words: Literature, law, and rebellion in Shakespeare's England. Cornell University Press: Ithaca, NY.

Maguire L and Smith E (2012) Many Hands-A New Shakespeare Collaboration? Times Literary Supplement 19 April, 13-15.

Murray J (1990) On the origins and role of "wise women" in causes of annulment on the grounds of male impotence. Journal of Medieval History; 16 (3): 235-249.

Nicholls M (1991) Investigating Gunpowder Plot. Manchester University Press: Manchester, UK.

Nuttall AD (2007) Shakespeare the Thinker. Yale University Press: New Haven, CT.

Patterson WB (1997) King James VI and I and the Reunion of Christendom. Cambridge University Press: Cambridge, UK

Questier MC (1997) Loyalty, religion and state power in early modern England: English Romanism and the Jacobean Oath of allegiance. The Historical Journal; 40 (2): 311-329.

Ryan CJ (1942) The Jacobean Oath of Allegiance and English Lay Catholics. Catholic Historical Review; 28 (2): 159-183.

Schanzer E (1963) The Problem Plays of Shakespeare: A Study of Julius Caesar, measure for measure, Antony and Cleopatra. Routledge: London.

Shakespeare W (1912) Lowes JL (ed) All's Well That Ends Well. Palgrave Macmillan: New York.

Shakespeare W (1929) Wilson JD and Quiller-Couch A (ed) All's Well That Ends Well. Cambridge University Press: Cambridge, UK.

Shakespeare W (1959) Hunter GK (ed) Well That Ends Well. Methuen: London.

Shakespeare W (1993) Snyder S (ed) All's Well That Ends Well. Oxford University Press: Oxford

Skinner Q (2014) Forensic Shakespeare. Oxford University Press: Oxford

Smith E (2008) Shakespeare's Comedies: A Guide to Criticism. Wiley-Blackwell: Oxford.

Sokol BJ and Sokol M (2000) Shakespeare's Legal Language: A Dictionary. Athlone: London.

Traister BH (2003) "Doctor she": Healing and sex in All's Well That Ends Well. In: Dutton R and Howard JE (eds). A Companion to Shakespeare's Works; Vol. 4 Blackwell: Oxford, pp 332-347.

Wilson R (2005) To great St Jaques Bound: All's Well That Ends Well in Shakespeare's Europe. Shakespeare et l'Europe de la Renaissance; 22, 273-290.

Woods G (2013) Shakespeare's Unreformed Fictions. Oxford University Press: Oxford.

Zagorin P (1990) Ways of Lying: Dissimulation and Conformity in Early Modern Europe. Harvard University Press: Cambridge, MA.

\section{Data availability}

Data sharing not applicable to this article as no data sets were generated or analysed during the current study.

\section{Additional information}

Competing interests: The authors declare no competing financial interests.

Reprints and permission information is available at http://www.palgrave-journals.com/ pal/authors/rights_and_permissions.html

How to cite this article: Hadfield A (2016) Bad faith in All's Well That Ends Well. Palgrave Communications. 2:16051 doi: 10.1057/palcomms.2016.51.

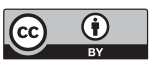

This work is licensed under a Creative Commons Attribution 4.0 International License. The images or other third party material in thi article are included in the article's Creative Commons license, unless indicated otherwise in the credit line; if the material is not included under the Creative Commons license, users will need to obtain permission from the license holder to reproduce the material. To view a copy of this license, visit http://creativecommons.org/licenses/by/4.0/ 